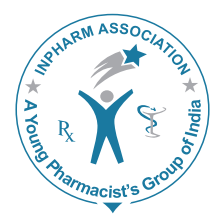

\title{
Assessment of learning domains to improve student's learning in higher education
}

\author{
Gowrishankar Kasilingam*, Mritha ramalingam, Elanchezian Chinnavan
}

\author{
${ }^{1}$ Faculty of Engineering and Computer Technology, ${ }^{1}$ School of Physiotherapy, \\ AIMST University, Kedah, Malaysia
}

\begin{abstract}
Objectives: To discuss the behavior of three different learning domains and effective assessment of each domain. Materials and Methods: Learning domains have always played an important role in evaluating the student's knowledge and skills. The learning domains can be incorporated, while designing the course outcomes of all the courses in a program; however, the assessment of learning domains practiced in many higher education programs resulted in vague assessment methods and as a result, they failed to show concrete continual quality improvement (CQI). Hence, the authors have developed an assessment method, which is more holistic to assess the cognitive, affective, and psychomotor behaviors individually. Results: It is expected that the proposed method will allow one to objectively evaluate whether the students have achieved the criteria, subsequently facilitating CQI implementation within the program and produce qualified graduates. Conclusion: The proposed assessment method for learning domains will encourage readers to use reliable and valid assessments in higher education by discriminating between assessing skills, knowledge, and attitudes. This paper will inspire its readers to enhance association of teaching and learning. Application: Though, the examples used in the proposed method are taken from engineering education, this proposed assessment method can be applied to any higher education programs in medical, pharmaceutical technology, physiotherapy, bio-technology, etc.
\end{abstract}

Key words: Affective, assessment, cognitive, learning domains, psychomotor

\section{INTRODUCTION}

During 1950's, Benjamin Bloom led a team of educational psychologists in the analysis of academic learning behaviors. He aimed to develop a system with different categories of learning behavior to assist in the design

\begin{tabular}{|c|l|}
\hline \multicolumn{2}{|c|}{ Access this article online } \\
\hline Journal Sponsor & $\begin{array}{l}\text { Website: } \\
\text { www.jyoungpharm.org }\end{array}$ \\
\cline { 2 - 2 } & $\begin{array}{l}\text { DOI: } \\
\text { www.phcog net }\end{array}$ \\
\cline { 2 - 2 } & \\
\hline
\end{tabular}

and assessment of educational learning. ${ }^{1}$ The results of this research produced what is known today in the field of education as Bloom's taxonomy. Bloom's taxonomy provides a consistent means of developing the single most powerful tool for the assessment of student program outcomes (PO) - the learning or performance objective. A goal of Bloom's taxonomy is to motivate educators to focus on all the three domains, creating a more holistic form of education. Educators concerned with learning theory have given considerable thought to various types of learning in higher education providers. Bloom's taxonomy divides the educational objectives into three domains: cognitive domain, psychomotor domain and affective domain. Within each domain are multiple levels

\footnotetext{
*Address for correspondence:

Mr. Gowrishankar Kasilingam, Faculty of Engineering and Computer Technology, AIMST University, Kedah, Malaysia.

E-mail: gowri200@yahoo.com
} 
of learning that progress from more basic, surface-level learning to more complex, deeper-level learning. The level of learning we strive to impact will vary across learning experiences depending on (1) the nature of the experience, (2) the developmental levels of the participating students and (3) the duration and intensity of the experience.

Bloom's taxonomy is a multi-tiered model of classifying thinking according to six cognitive levels of complexity. Throughout the study year, the levels have often been depicted as a stairway, leading many teachers to encourage their students to "climb to a higher level of thought." The lowest three levels are: Knowledge, comprehension, and application. The highest three levels are: analysis, synthesis and evaluation. The taxonomy is hierarchical; each level is combined by the higher levels. In other words, a student functioning at the 'application' level has also mastered the material at the "knowledge" and "comprehension" levels. One can easily see how this arrangement led to natural divisions of lower and higher level of thinking, and it is applicable to affective and psychomotor domains also. In 2001, a former student of Bloom, Lorin Anderson, led a new assembly, which met for the purpose of updating the taxonomy relevant to the $21^{\text {st }}$ century students and teachers. ${ }^{2,3}$ Design of learning domain is carried out based on the inputs from cognitive psychologists, curriculum theorists and instructional researchers, and testing and assessment specialists. The designed learning domains are:

- Cognitive: Mental skills (knowledge), consisting six levels.

- Affective: Growth in feelings or emotional areas (attitude), consisting five levels.

- Psychomotor: Manual or physical skills (skills), consisting seven levels.

This paper deals essentially with implementation and assessment of learning domain behavior of the students addressed to outcome based education in higher education. The rest of the paper is organized as follows. Section 2 discusses the materials and methods of the learning domains. Section 3 explains the assessment method of learning domains and finally Section 4 concludes the paper.

\section{MATERIALS AND METHODS}

This section discusses the assessment method, which is more holistic with specific performance criteria toward cognitive, affective, and psychomotor domains. This paper also produces a format for the assessment of learning domains in an effective way.

\section{Cognitive domain}

Cognitive domain deals with how a student acquires processes and utilizes the knowledge. It is the "thinking" domain. This domain focuses on intellectual skills and is familiar to educators. Bloom's taxonomy (knowledge, comprehension, application, analysis, synthesis, and evaluation) is frequently used to describe the increasing complexity of cognitive skills as students move forward from a beginner to more advance level in their knowledge. Cognitive domain is the core of the learning domain. The other two domains (affective and psychomotor) require at least some of the cognitive components. The cognitive domain is well-suited for online environment of assessment. ${ }^{4}$ Courses that are hybrid (both online and face-to-face mode), often present the cognitive portion of the course through the web and use classroom teaching-learning methods for affective, psychomotor, and interpersonal course outcomes (COs). ${ }^{5}$ The levels in the cognitive domain can be measured through:

- Class discussions - refreshing previous lectures

- Organized class notes

- Tutorials

- Provide sufficient information through charts

- Power point slides

- Real time examples

- Self-check quizzes

- Project/problem based learnings

- Conducting course seminars and viva voce

- Practice questions with answers and "expert" explanations.

As we move up the cognitive domain, especially to synthesis and evaluation, collaborative assignments requiring students to engage in the problem or projectbased activities serve as an important way to determine whether the students have achieved that level of learning or not. These projects can be done online, but often lend themselves to at least some face-to-face interaction. If face-to-face interaction is not possible, synchronous mediated events such as web casting, interactive video, or conference calls facilitate project development. Furthermore, higher cognitive skills provide opportunities for a student to develop interpersonal domain learning. Now, the accreditation board of many countries insisted the higher education providers to implement the synthesis and evaluation from student's initial year of study onwards. Table 1 outlines the six levels in the cognitive domain and keywords that can be used to write learning objectives.

Journal of Young Pharmacists Vol 6 • Issue 1 • Jan-Mar 2014 
Table 1: Cognitive domain

\begin{tabular}{|c|c|c|}
\hline \multicolumn{3}{|c|}{ Increasing complexity } \\
\hline Domain & Description & Keywords \\
\hline $\begin{array}{l}\text { Remember } \\
\text { Recalling important information }\end{array}$ & $\begin{array}{l}\text { Retrieve relevant knowledge form long term } \\
\text { memory }\end{array}$ & $\begin{array}{l}\text { Define, repeat, record, list, recall, name, relate, } \\
\text { underline }\end{array}$ \\
\hline $\begin{array}{l}\text { Understand } \\
\text { Explaining important information }\end{array}$ & $\begin{array}{l}\text { Understand, translate, explain facts, concepts, } \\
\text { principles, laws and theories or comprehension }\end{array}$ & $\begin{array}{l}\text { Translate, restate, discuss, describe, recognize, } \\
\text { explain, express, identify, locate, report and review }\end{array}$ \\
\hline $\begin{array}{l}\text { Apply } \\
\text { Solving closed-ended problems }\end{array}$ & $\begin{array}{l}\text { Use facts, concepts, laws, theories, principles, } \\
\text { knowledge and skills to solve related problems }\end{array}$ & $\begin{array}{l}\text { Interpret, apply, employ, use, demonstrate, dramatize, } \\
\text { practise, illustrate, operate, schedule and sketch }\end{array}$ \\
\hline $\begin{array}{l}\text { Analyze } \\
\text { Solving open-ended problems }\end{array}$ & $\begin{array}{l}\text { Compare and elaborate the similarities, } \\
\text { differences and relationship between one and } \\
\text { the other }\end{array}$ & $\begin{array}{l}\text { Distinguish, analyse, solve, differentiate, appraise, } \\
\text { debate, calculate, experiment, test, compare, } \\
\text { contrast, criticize, diagram, inspect, question, relate, } \\
\text { examine and categorize }\end{array}$ \\
\hline $\begin{array}{l}\text { Synthesis } \\
\text { Creating "unique" answers to } \\
\text { problems }\end{array}$ & Merge, combine and integrate facts and ideas & $\begin{array}{l}\text { Compose, plan, propose, design, formulate, arrange, } \\
\text { assemble, collect, construct, create, set up, organize, } \\
\text { manage and prepare }\end{array}$ \\
\hline $\begin{array}{l}\text { Evaluation } \\
\text { Making critical judgments based } \\
\text { on a sound knowledge base }\end{array}$ & $\begin{array}{l}\text { Prove, evaluate, verify, criticize, conclude } \\
\text { or to give opinion on a statement, invention, } \\
\text { principles, theories etc. }\end{array}$ & $\begin{array}{l}\text { Judge, appraise, evaluate, rate, compare, revise, } \\
\text { assess and estimate }\end{array}$ \\
\hline
\end{tabular}

\section{Affective domain}

Affective domain is critical for learning, but is often not specifically addressed. This domain focuses on attitude, motivation, willingness to participate, valuing what is being learned and ultimately incorporating the discipline values into real life. Stages in this domain are not as sequential as the cognitive domain, but have been described as the following:

- Receiving (willing to listen)

- Responding (willing to listen)cifically addres

- Valuing (willing to be involved)

- Organizing (willing to be av advocate)

- Characterization (willing to change one's behavior, lifestyle, or way of life).

Teachers usually expect the students to be willing to "show up," participate in teaching-learning activity, expend the effort in their courses and sustain the effort throughout the course duration. Furthermore, the teachers would like the students to proceed to the next higher level course in the curriculum as they value what they have learned.

The affective domain is not best handled with just text on a screen. Class meetings or an initial class meeting to support an online course might be used for affective development. Videos and audio clips are also excellent ways to engage the affective domain. These should be short and may include the following:

- Feedback from alumni on how to be successful.

- Lecturers-students discussion on course value.

- Conducting Quiz at regular intervals.

- Examples of professionals applying the learned course knowledge in their lives.

- Conducting course-wise guest lectures.
- Streaming audio files throughout the course to encourage students' teaching-learning activity.

- Encourage students' visit to programme related organizations

- Short video clips of the instructor explaining course content.

To design COs for the courses by giving importance to affective learning domain, the inputs can be collected from alumni, academic advisory panel members, industry advisory panel members, lecturers, and other stakeholders. Face-toface courses can include affective online components by allowing students to raise questions, get feedback and hear encouraging messages from the instructor.

Motivate the students to set individual objectives that are reasonable can also enhance affective learning. To the extent how the students are challenged or new to content, we would expect the educators to include level of the affective domain in COs. Table 2 outlines the five levels in the affective domain and keywords that can be used to write learning objectives.

\section{Psychomotor domain}

Psychomotor domain focuses on performing sequences of motor activities to a specified level of accuracy, smoothness, rapidity, or force. Underlying the motor activity is cognitive understanding. In the higher education environment, psychomotor learning can be included in the following contents:

- Lab courses for science classes

- Vocational courses

- Physical education courses

- Training using specified equipment such as computers, projectors, videos etc.

- Performing arts. 
The stages of the psychomotor domain have been described as follows:

- Action (elementary movement)

- Coordination (synchronized movement)

- Formation (bodily movement)

- Production (verbal and nonverbal movement).

The psychomotor domain is best assessed in a faceto-face situation. Since there is a cognitive component underlying motor skills, these can be effectively observed through videos, demonstrations, online text descriptions, or with pictures of each step in the sequence. Simulations can be used to help people to learn the steps or practice variations of a motor sequence. However ultimately,

Table 2: Affective domain

\begin{tabular}{|c|c|c|}
\hline \multicolumn{3}{|c|}{ Increasing complexity } \\
\hline Domain & Description & Keywords \\
\hline $\begin{array}{l}\text { Receiving } \\
\text { Willing to } \\
\text { listen }\end{array}$ & $\begin{array}{l}\text { Awareness, } \\
\text { willingness to } \\
\text { hear, selected } \\
\text { attention }\end{array}$ & $\begin{array}{l}\text { Ask, choose, } \\
\text { describe, follow, } \\
\text { identify, locate, } \\
\text { name, select, reply, } \\
\text { use }\end{array}$ \\
\hline $\begin{array}{l}\text { Responding } \\
\text { Willing to } \\
\text { participate }\end{array}$ & $\begin{array}{l}\text { Active } \\
\text { participation, } \\
\text { interaction } \\
\text { or response } \\
\text { to new } \\
\text { information or } \\
\text { experiences }\end{array}$ & $\begin{array}{l}\text { Answer, assist, aid, } \\
\text { compile, conform, } \\
\text { discuss, help, label, } \\
\text { perform, practice, } \\
\text { present, read, } \\
\text { recite, report, select, } \\
\text { tell, write }\end{array}$ \\
\hline $\begin{array}{l}\text { Valuing } \\
\text { Willing to be } \\
\text { involved }\end{array}$ & $\begin{array}{l}\text { Value or worth } \\
\text { a person } \\
\text { attaches to } \\
\text { particular } \\
\text { object, } \\
\text { phenomenon } \\
\text { or behavior. } \\
\text { This ranges } \\
\text { from simple } \\
\text { acceptance to } \\
\text { more complex } \\
\text { state of } \\
\text { commitment }\end{array}$ & $\begin{array}{l}\text { Complete, } \\
\text { demonstrate, } \\
\text { differentiate, } \\
\text { explain, follow, } \\
\text { form, initiate, join, } \\
\text { justify, propose, } \\
\text { read, share, study, } \\
\text { work }\end{array}$ \\
\hline $\begin{array}{l}\text { Organization } \\
\text { Willing to be } \\
\text { an advocate }\end{array}$ & $\begin{array}{l}\text { Incorporating } \\
\text { new } \\
\text { information or } \\
\text { experiences } \\
\text { to existing } \\
\text { system }\end{array}$ & $\begin{array}{l}\text { Adhere, alter, } \\
\text { arrange, combine, } \\
\text { compare, complete, } \\
\text { defend, formulate, } \\
\text { generalize, identify, } \\
\text { integrate, modify, } \\
\text { order, organize, } \\
\text { prepare, relate, } \\
\text { synthesize }\end{array}$ \\
\hline $\begin{array}{l}\text { Characterization } \\
\text { Willing to } \\
\text { change one's } \\
\text { behavior, } \\
\text { lifestyle, or } \\
\text { way of life }\end{array}$ & $\begin{array}{l}\text { Value system } \\
\text { that controls } \\
\text { their behavior. } \\
\text { The behavior } \\
\text { is pervasive, } \\
\text { consistent, } \\
\text { predictable } \\
\text { and most } \\
\text { importantly, } \\
\text { characteristic } \\
\text { of the learner }\end{array}$ & $\begin{array}{l}\text { Act, discriminate, } \\
\text { display, influence, } \\
\text { listen, modify, } \\
\text { perform, practice, } \\
\text { propose, qualify, } \\
\text { question, revise, } \\
\text { serve, solve, verify, } \\
\text { use }\end{array}$ \\
\hline
\end{tabular}

the student should perform the skill with an instructor or designee judging if the skill was performed to a set standard. Sometimes, simulations are used for learning without "hands on" opportunities. Students who are new to a content area will generally benefit more from "hands-on" learning than from mediated learning within the psychomotor domain. As students improve to expert, videos and pictures can be used to teach the skill. Table 3 outlines the seven levels in psychomotor domain and keywords that can be used to write learning objectives.

Table 3: Psychomotor domain

\begin{tabular}{|c|c|c|}
\hline \multicolumn{3}{|c|}{ Psychomotor domain } \\
\hline Domain & Description & Keywords \\
\hline $\begin{array}{l}\text { Perception } \\
\text { Senses cues } \\
\text { that guided } \\
\text { motor activity }\end{array}$ & $\begin{array}{l}\text { Uses senses } \\
\text { organs to obtain } \\
\text { cues to guide } \\
\text { action: ranges } \\
\text { from awareness } \\
\text { of stimulus to } \\
\text { translating cue } \\
\text { perception into } \\
\text { action }\end{array}$ & $\begin{array}{l}\text { Choose, describe, } \\
\text { detect, differentiate, } \\
\text { distinguish, identify, } \\
\text { isolate, relate, select, } \\
\text { separate }\end{array}$ \\
\hline $\begin{array}{l}\text { Set } \\
\text { Is mentally, } \\
\text { emotionally and } \\
\text { physically ready } \\
\text { to act }\end{array}$ & $\begin{array}{l}\text { Readiness to take } \\
\text { action: includes } \\
\text { mental, physical } \\
\text { and emotional set }\end{array}$ & $\begin{array}{l}\text { Begin, display, explain, } \\
\text { move, proceed, react, } \\
\text { respond, show, start, } \\
\text { volunteer }\end{array}$ \\
\hline $\begin{array}{l}\text { Guided response } \\
\text { Imitates and } \\
\text { practices skills, } \\
\text { often in discrete } \\
\text { steps }\end{array}$ & $\begin{array}{l}\text { Knowledge of the } \\
\text { steps required to } \\
\text { perform a task: } \\
\text { includes imitation } \\
\text { and trial and error }\end{array}$ & $\begin{array}{l}\text { Copies, traces, follows, } \\
\text { react, reproduce, } \\
\text { responds }\end{array}$ \\
\hline $\begin{array}{l}\text { Mechanism } \\
\text { Performs acts } \\
\text { with increasing, } \\
\text { efficiency, } \\
\text { confidence and } \\
\text { proficiency }\end{array}$ & $\begin{array}{l}\text { Perform tasks in a } \\
\text { habitual manner: } \\
\text { with a degree of } \\
\text { confidence and } \\
\text { proficiency }\end{array}$ & $\begin{array}{l}\text { assembles, calibrates, } \\
\text { constructs, dismantles, } \\
\text { displays, fastens, } \\
\text { fixes, grinds, heats, } \\
\text { manipulates, } \\
\text { measures, mends, } \\
\text { mixes, organizes, } \\
\text { sketches }\end{array}$ \\
\hline $\begin{array}{l}\text { Complex overt } \\
\text { response } \\
\text { Performs } \\
\text { automatically }\end{array}$ & $\begin{array}{l}\text { Skill performance } \\
\text { of motor acts } \\
\text { involving complex } \\
\text { patterns of } \\
\text { movement }\end{array}$ & $\begin{array}{l}\text { assembles, builds, } \\
\text { calibrates, constructs, } \\
\text { dismantles, displays, } \\
\text { fastens, fixes, grinds, } \\
\text { heats, manipulates, } \\
\text { measures, mends, } \\
\text { mixes, organizes, } \\
\text { sketches }\end{array}$ \\
\hline $\begin{array}{l}\text { Adaptation } \\
\text { Adapts skill to } \\
\text { meet a problem } \\
\text { situation }\end{array}$ & $\begin{array}{l}\text { Modifies } \\
\text { movement } \\
\text { patterns to } \\
\text { account for } \\
\text { problematic or } \\
\text { new situations }\end{array}$ & $\begin{array}{l}\text { Adapt, alter, chance, } \\
\text { rearrange, reorganize, } \\
\text { revise, vary }\end{array}$ \\
\hline $\begin{array}{l}\text { Origination } \\
\text { Creates new } \\
\text { patterns } \\
\text { for specific } \\
\text { situations }\end{array}$ & $\begin{array}{l}\text { Creating new } \\
\text { movement } \\
\text { patterns to } \\
\text { account for } \\
\text { problematic or } \\
\text { new situations; } \\
\text { creates new tasks } \\
\text { that incorporate } \\
\text { learned ones }\end{array}$ & $\begin{array}{l}\text { Arranges, builds, } \\
\text { combines, composes, } \\
\text { constructs, creates, } \\
\text { designs, initiate, } \\
\text { makes, originates }\end{array}$ \\
\hline
\end{tabular}

Journal of Young Pharmacists Vol 6 • Issue 1 • Jan-Mar 2014 


\section{Assessment of learning domains}

COs are statements that describe significant and essential learning that learners have achieved and can reliably demonstrate at the end of a course. This means the COs identify what the learner will understand and be able to do by the end of a course. ${ }^{6}$ COs should be measureable and observable through cognitive, psychomotor, and affective learning domains. In other words, COs should reflect essential knowledge, skills and attitudes and finally, represent the minimum performances that must be achieved upon successfully completing a course. CO is developed using Bloom's taxonomy that involves three learning domains: cognitive, affective and psychomotor. ${ }^{7}$ These learning domains can be measured through the crafting of COs. Initially, while designing COs for any particular course, it is necessary to mention the level of learning domains such as cognitive, affective and psychomotor that is to be achieved through a particular course. Table 4 shows a sample template of designing COs. As shown in Table 4, C represents Cognitive; A-Affective and P-Psychomotor domains. Table 4 clearly explains how an individual CO is linked with the POs and learning domains. The achievement of POs can be measured through Final exam, Mid Semester Exam, Laboratory, Assignments, etc. ${ }^{8}$ The assessment of learning domains is explained in Table 5.

Cognitive domain is easy to measure compared with other two domains. And also the assessment of the cognitive domain will have an impact on other domains. As mentioned earlier, designing of COs based on POs and learning domains, the cognitive domain of a particular course can be easily measured through final examination. While designing COs, the lecturers decide the level of cognitive to be achieved by the end of the course. Now, most of the higher education providers insisted their examiners to set question paper to achieve a minimum of $25 \%$ of cognitive levels C5 and C6. A student who is able to answer the higher (C5 and C6) cognitive level questions, indirectly shows that the particular student can achieve the affective and psychomotor domains. Table 6 shows the level of cognitive mentioned in each questions.

The template in Table 6 explains how to set questions involving different cognitive levels. Based on Table 6 values, the achievement of cognitive levels of each student can be measured using the template in Table 7. After evaluation, the percentage of cognitive level achieved by individual student can be measured. The improvement can be done based on the feedback from co-lecturers, modification in teaching methodology, etc. It is the responsibility of the lecturer for each course to maintain a detailed course syllabus, which carefully delineates both the content and learning domains addressed by the course. The syllabus should also contain course objectives, instructional techniques, and evaluation methods.

There are two primary purposes of an affective evaluation system: (1) To verify competence in the affective domain, and (2) to serve as a method to change behavior. Affective domain focuses on receiving, responding, valuing, organizing, and characterization. Quiz can be conducted based on the previous class lectures, by streaming course videos, lecture notes, etc. Here, we are doing the assessment based on interaction quiz from the video presentation.

Table 4: Template of COs with POs and learning domains

\begin{tabular}{lcl}
\hline COs & Description & POs and learning domains \\
\hline $\mathrm{CO} 1$ & - & $\mathrm{PO}, \mathrm{PO}, \mathrm{C} 3, \mathrm{~A} 3, \mathrm{P} 3$ \\
$\mathrm{CO} 2$ & - & $\mathrm{PO}, \mathrm{PO} 4, \mathrm{PO}, \mathrm{PO}, \mathrm{C} 6, \mathrm{~A} 4, \mathrm{P} 4$ \\
$\mathrm{CO} 3$ & - & $\mathrm{PO}, \mathrm{PO} 4, \mathrm{PO}, \mathrm{PO}, \mathrm{C} 6, \mathrm{~A} 5, \mathrm{P} 7$ \\
\hline
\end{tabular}

COs: Course outcomes, POs: Programme outcomes

Table 5: Assessment of learning domains

\begin{tabular}{|c|c|c|}
\hline \multicolumn{3}{|c|}{ Assessment method } \\
\hline Cognitive & Affective & Psychomotor \\
\hline $\begin{array}{l}\text { Previous class } \\
\text { discussions } \\
\text { Tutorials } \\
\text { Real time examples } \\
\text { Self-check quizzes } \\
\text { Project based learning } \\
\text { Problem based learning } \\
\text { Practice questions with } \\
\text { answers and "expert" } \\
\text { explanations } \\
\text { Conducting course } \\
\text { seminars and viva voce } \\
\text { Final examination }\end{array}$ & $\begin{array}{l}\text { Conducting quiz } \\
\text { Conducting } \\
\text { course-wise guest } \\
\text { lectures } \\
\text { Professionals } \\
\text { who are using the } \\
\text { knowledge from the } \\
\text { course in their lives } \\
\text { Project report } \\
\text { writing } \\
\text { Streaming audio } \\
\text { files throughout the } \\
\text { course encouraging } \\
\text { students and } \\
\text { providing helpful } \\
\text { tips } \\
\text { Industrial visits } \\
\text { Short video clips } \\
\text { of the instructor } \\
\text { explaining course } \\
\text { content }\end{array}$ & $\begin{array}{l}\text { Final year } \\
\text { project } \\
\text { Laboratory } \\
\text { Mini-project } \\
\text { Attending } \\
\text { project } \\
\text { exhibition } \\
\text { Industrial visits } \\
\text { Industrial } \\
\text { in-plant } \\
\text { training }\end{array}$ \\
\hline
\end{tabular}

Table 6: Setting of questions using different cognitive levels

\begin{tabular}{|c|c|c|c|c|c|}
\hline \multirow[t]{2}{*}{ Questions } & \multirow[t]{2}{*}{ Examples } & \multicolumn{4}{|c|}{$\begin{array}{c}\text { Bloom's taxanomy } \\
\text { level }\end{array}$} \\
\hline & & $\mathrm{C} 1$ & C2 & C3 C4 & $\mathrm{C} 5 \mathrm{C6}$ \\
\hline 1 & $\begin{array}{l}\text { Explain the concepts of open } \\
\text { loop and closed loop system }\end{array}$ & & $\bullet$ & & \\
\hline 2 & $\begin{array}{l}\text { Define rise time, peak time and } \\
\text { maximum peak overshoot }\end{array}$ & • & & & \\
\hline 3 & $\begin{array}{l}\text { Derive the transfer function of } \\
\text { field controlled DC motor }\end{array}$ & & & - & \\
\hline 4 & $\begin{array}{l}\text { Sketch the rootlocus for the } \\
\text { system and determine the value } \\
\text { of } \mathrm{K} \text { when damping ratio is } 0.5\end{array}$ & & & & $\bullet$ \\
\hline 5 & $\begin{array}{l}\text { Design PID controller for the } \\
\text { system using bode plot method }\end{array}$ & & & & $\bullet$ \\
\hline
\end{tabular}

PID: Proportional integral derivative 
Table 7: Template for the assessment of cognitive domain

\begin{tabular}{|c|c|c|c|c|}
\hline \multicolumn{5}{|c|}{ Assessment for cognitive domain } \\
\hline Level & Domain & Description & Achieved & Not achieved \\
\hline $\mathrm{C} 1$ & Remember & Explain the concepts of open loop and closed loop system & & \\
\hline $\mathrm{C} 2$ & Understand & Define rise time, peak time and maximum peak overshoot & & \\
\hline $\mathrm{C} 3$ & Apply & Derive the transfer function of field controlled DC motor & & \\
\hline $\mathrm{C} 4$ & Analyze & Sketch the root locus for the system and determine the value of $\mathrm{K}$ when damping ratio is 0.5 & & \\
\hline $\mathrm{C} 5$ & Synthesis & Design PID controller for the system using bode plot method & & \\
\hline C6 & Evaluation & Justify your answer for the proposed design & & \\
\hline
\end{tabular}

PID: Proportional integral derivative

Table 8 explains how to assess affective domain through the quiz for a video presentation.

The template in Table 8 can also be used to assess seminar presentation and guest lecture. Finally at the end of each course, average affective level assessment can be calculated for the individual student. This method shows the calculation of the affective domain in an effective way.

Psychomotor assessment consists of several levels namely,

- Identifying the practical skills

- Designing laboratory practical test

- Developing skill assessment form.

Laboratory manual in the laboratory were analyzed and reviewed. The common procedures and tasks for each laboratory experiments were grouped according to the practical skills performed by students. Later, the lecturers compare the practical skills that have been identified with the psychomotor domain model. Table 9 shows the identified practical skills and the mapping of skills to the psychomotor domain.

In order to identify the practical skills acquired by the students, the lecturer has to develop assessment rubric. This rubric was designed subsequent to the analysis of the laboratory experiment and the design of the laboratory practical test. This rubric was used by the lecturers as a checklist in identifying the students' practical skills in performing the tasks specified in the practical test. Table 10 illustrates the sample assessment rubric.

The items in Table 10 were categorized into different groups based on comparison made between practical skills with psychomotor domain. The groups were arranged in the sequences of work performed by students during the experiments. For example, the items 1,2, and 3 are focused on the students' ability to recollect the basics needed for that experiment. Students' ability to determine the components, values and the polarity of the components was also categorized under this category. Item 4 is focused on the students' ability to construct the circuit. Items 5-9 tested the students' ability to operate the instruments, which include
Table 8: Template for the assessment of affective domain

\begin{tabular}{|c|c|c|c|c|}
\hline \multicolumn{5}{|c|}{ Assessment rubric for affective domain } \\
\hline Level & Domain & Description & Able & Not able \\
\hline$\overline{\mathrm{A} 1}$ & Receiving & $\begin{array}{l}\text { Receiving information from } \\
\text { the videos }\end{array}$ & & \\
\hline A2 & Responding & Answering for the questions & & \\
\hline A3 & Valuing & $\begin{array}{l}\text { Explaining the concepts } \\
\text { involved }\end{array}$ & & \\
\hline A4 & Organization & $\begin{array}{l}\text { Modify the existing } \\
\text { concepts with new ideas }\end{array}$ & & \\
\hline A5 & Characterization & $\begin{array}{l}\text { Use the concept to change } \\
\text { his behavior or life style }\end{array}$ & & \\
\hline
\end{tabular}

Table 9: Template of mapping skills to psychomotor domain

\begin{tabular}{|c|c|c|}
\hline Tasks & Description & $\begin{array}{l}\text { Psychomotor } \\
\text { domain level }\end{array}$ \\
\hline $\begin{array}{l}\text { Name and Identify } \\
\text { the component }\end{array}$ & $\begin{array}{l}\text { Able to identify the } \\
\text { components }\end{array}$ & Perception \\
\hline $\begin{array}{l}\text { Sketch/identify the } \\
\text { symbols }\end{array}$ & $\begin{array}{l}\text { Able to draw the relevant } \\
\text { circuit }\end{array}$ & Perception \\
\hline $\begin{array}{l}\text { Explain the function } \\
\text { of components }\end{array}$ & $\begin{array}{l}\text { Able to explain the } \\
\text { working principle }\end{array}$ & Perception \\
\hline Construct circuit & $\begin{array}{l}\text { Developing circuit diagram } \\
\text { based on design values }\end{array}$ & Mechanism \\
\hline Connection & $\begin{array}{l}\text { Implementation of circuit } \\
\text { diagram }\end{array}$ & $\begin{array}{l}\text { Guided } \\
\text { response }\end{array}$ \\
\hline $\begin{array}{l}\text { Theoretical } \\
\text { calculation }\end{array}$ & $\begin{array}{l}\text { Theoretical evaluation of } \\
\text { output results }\end{array}$ & $\begin{array}{l}\text { Guided } \\
\text { response }\end{array}$ \\
\hline Practical readings & $\begin{array}{l}\text { Comparing theoretical } \\
\text { with practical values }\end{array}$ & $\begin{array}{l}\text { Guided } \\
\text { response }\end{array}$ \\
\hline Inference & $\begin{array}{l}\text { Understanding of } \\
\text { experiment }\end{array}$ & Adaptation \\
\hline
\end{tabular}

connecting the instruments and calibrating them. Finally, the students' ability to interpret the measuring instrument's indication is described by items 10 and 11 . Using this idea, we can easily measure whether the students have achieved the level of psychomotor mentioned in design of COs.

\section{RESULTS AND DISCUSSION}

The learning domain assessment is continuous starting from the first week until the last week of lecture. At the end of the course learning process and assessment, all the lecturers must do the course evaluation in order to analyze the student achievement in terms of PO and taxonomy level. Results may imply needed change in

Journal of Young Pharmacists Vol 6 • Issue 1 • Jan-Mar 2014 
Table 10: Sample assessment Rubric for Electronics Laboratory

\begin{tabular}{|c|c|c|}
\hline Item & Skill & Able Not able \\
\hline \multicolumn{3}{|c|}{ Able to recollect the basics } \\
\hline 1 & Resistor (symbol and value - color code) & \\
\hline 2 & Inductor (symbol) & \\
\hline 3 & Capacitor, transistor etc., (symbol) & \\
\hline \multicolumn{3}{|c|}{ Able to construct the circuit } \\
\hline 4 & Construct the circuit on bread board & \\
\hline \multicolumn{3}{|c|}{ Able to operate the meters, instruments etc. } \\
\hline 5 & Connect meters to the circuit & \\
\hline 6 & Connect oscilloscope to the circuit & \\
\hline 7 & Set the input frequency in function generator & \\
\hline 8 & Set the amplitude in function generator & \\
\hline \multirow[t]{2}{*}{9} & Calibrate the oscilloscope & \\
\hline & $\begin{array}{l}\text { Able to conduct and compare obtained result } \\
\text { with theoretical calculation }\end{array}$ & \\
\hline 10 & Record the waveform from oscilloscope & \\
\hline 11 & Analyze the results & \\
\hline
\end{tabular}

contents, CO's, curriculum or the POs. It is expected that the proposed method will allow one to objectively evaluate whether the students have achieved the criteria, subsequently facilitating continual quality improvement implementation within the program and produced quality engineering graduates.

The method is objectively analyzed to pinpoint the weaknesses and areas for further improvement. Through this analysis, we hope an improved method has been suggested, which will be more effective and practical.

\section{CONCLUSION}

From the proposed method, it is highly recommended that the current assessment method can be modified based on the revision of the course outline toward the achievement of learning domains. The new assessment method should specifically assess students' knowledge and practical skills with respect to laboratory experiments, assignments, quizzes, etc. This paper proposed the levels of learning domain skills acquired by students after completing all the courses with reference to learning domain taxonomy. A comprehensive assessment of students' performance in the courses is important in producing graduates who are able to integrate the theory and practice of the learned courses in any higher education programs.

\section{REFERENCES}

1. Bloom BS, editor. Taxonomy of Educational Objectives: The Classification of Educational Goals: Handbook I, Cognitive Domain. New York; Toronto: Longmans, Green; 1956.

2. Anderson LW, Krathwohl DR, Airasian PW, Cruikshank KA, Mayer RE, Pintrich PR, et al. Taxonomy for learning, teaching, and assessing a revision of Bloom's taxonomy of educational objectives. Abridged Ed. New York: Addison Wesley Longman, Inc.; 2001.

3. Anderson LW. Research on teaching and teacher education. In: Anderson LW, Sosniak LA, editors. Bloom's Taxonomy a Forty-Year Retrospective, Yearbook of the National Society for the Study of Education. Vol. 93. No. 2. Chicago, Illinois: The University of Chicago Press; 1994. p. $126-45$.

4. Hoffmann M. Using Bloom's Taxonomy of Learning to Make Engineering Course Comparable. European Association for Education in Electrical and Information Engineering; 2008.

5. Alinier N, Alinier G. Design of an objective assessment tool to evaluate students' basic electrical engineering skills. The Higher Education AcademyEngineering Subject Centre; 2005.

6. Harlen W. Assessment of Learning. Los Angeles: SAGE Publications; 2007.

7. Zaghloul A. Assessment of lab work: A three-domain model; cognitive, affective and psychomotor. ASEE Annual Conference \& Exposition; 2001.

8. Davies C. Learning and teaching in laboratories. Teaching-Guides/ Laboratories; 2008. 